http://dx.doi.org/10.18778/8088-164-8.02

\title{
Radostaw Bania
}

Uniwersytet Łódzki

\section{POWSTANIE TZW. PAŃSTWA ISLAMSKIEGO W IRAKU ${ }^{1}$}

Region Bliskiego Wschodu i Północnej Afryki (Middle East and North Africa - MENA) na początku XXI w. nadal jest powszechnie uznawany za jeden z największych obszarów niestabilności we współczesnym świecie. Region, który stanowi kolebkę wielu cywilizacji, na którego obszarze powstawały i rozwijały się wielkie religie monoteistyczne - judaizm, chrześcijaństwo i islam, wciąż pozostaje obszarem niepokojów i konfliktów. Ich wpływ nie ogranicza się wyłącznie do samego regionu bliskowschodniego, ale jednocześnie wywołuje reperkusje w innych obszarach globu ziemskiego, jak pokazały to chociażby ataki terrorystyczne na Stany Zjednoczone przeprowadzone przez członków Al-Kaidy 11 września $2001 \mathrm{r}$.

MENA to 21 państw zamieszkałych przez ponad $350 \mathrm{mln}$ ludzi ${ }^{2}$. Zdecydowana większość to kraje arabskie, chociaż nie całkowicie jednorodne pod względem etnicznym. Niejednorodna jest również struktura religijna współczesnego Bliskiego Wschodu. Państwa muzułmańskie są tu, oczywiście, dominujące, jednak wyznawcy islamu dzielą się na dwie główne odmiany - większość sunnicką i mniejszość szyicką. Przy czym oba odłamy islamu pozostają często w stanie mniej lub bardziej skrywanej wrogości, co jest efektem wielowiekowej już rywalizacji między nimi. Nie bez znaczenia jest również czynnik geopolityczny, wpływający na napięcia pomiędzy szyitami a sunnitami. W państwach arabskich dominuje islam sunnicki, natomiast głównym centrum szyizmu na Bliskim Wschodzie pozostaje Iran, uważany przez państwa arabskie za głównego konkurenta politycznego $\mathrm{w}$ regionie. Warto w tym miejscu podkreślić, że zasygnalizowany wyżej podział nie wyczerpuje rozłamów w świecie islamu. Także w ramach sunnizmu i szyizmu można wskazać różne, często konkurujące ze sobą odłamy i ugrupowania. Istnieją ponadto sekty, które funkcjonują na pograniczu

\footnotetext{
${ }^{1}$ Rozszerzona i uzupełniona przypisami wersja artykułu, który ukazał się w kwartalniku „Więż” (zima 2014, nr 4) pt. Dlaczego „Państwo Islamskie” zwycięża w Iraku.

${ }^{2}$ Middle East and North Africa, http://data.worldbank.org/region/MNA [dostęp 1.10.2015].
} 
obu głównych odgałęzień islamu, a częściowo również chrześcijaństwa, jak chociażby alawici czy druzowie ${ }^{3}$.

Współczesny system państw bliskowschodnich powstał w oparciu o nałożenie się na siebie dwóch procesów politycznych. Po pierwsze, rywalizacji o władzę lokalnych sił politycznych, a po drugie - ekspansji kolonialnej mocarstw europejskich. Niemal wszystkie współczesne państwa bliskowschodnie doświadczyły dominacji europejskiej jako kolonie, obszary mandatowe lub protektoraty. Należy również podkreślić, że istotnym wydarzeniem, które doprowadziło do rozszerzenia europejskiego kolonializmu na Bliskim Wschodzie, była klęska i rozpad Imperium Osmańskiego po zakończeniu I wojny światowej. Z pewnym uproszczeniem można przyjąć, że w latach 20. i 30. XX w. mocarstwa europejskie - Wielka Brytania i Francja dokonały podziału terytorialnego byłych bliskowschodnich prowincji tureckich, jednocześnie podejmując arbitralne decyzje o wyznaczeniu linii granicznych, czego efektem jest współczesna mapa polityczna Bliskiego Wschodu.

Jednym z przykładów kreowania sztucznych organizmów państwowych jest powstanie współczesnego Iraku. Na mocy decyzji mocarstw europejskich w jeden organizm państwowy połączono byłe osmańskie wilajety Mosulu, Bagdadu i Basry. Stworzono w ten sposób sztuczne państwo, w ramach którego znaleźli się sunnici, szyici oraz Kurdowie, a poza tym spowodowano powstanie zalążka późniejszych konfliktów wewnętrznych w Iraku. Powołanie do życia państwa irackiego służyło realizacji celów mocarstw europejskich, w tym przypadku Wielkiej Brytanii. W ten sposób łatwiej było kontrolować i wykorzystywać zasoby ropy naftowej znajdujące się w obszarze Mezopotamii i Kurdystanu. Utworzenie nowego państwa było również swego rodzaju zadośćuczynieniem dla jednego z brytyjskich protegowanych w regionie Bliskiego Wschodu z okresu I wojny światowej. Brytyjczycy wyznaczyli na monarchę Iraku emira Fajsala, pochodzącego z rządzącego w tym czasie Mekką arabskiego rodu Haszymidów ${ }^{4}$, do którego należał również prorok Muhammad. Fajsal zapoczątkował rządy dynastii panującej do $1958 \mathrm{r}$.

Irak formalnie uzyskał niepodległość w 1932 r. Również wtedy został przyjęty, jako niepodległe państwo, do Ligi Narodów. Pod względem politycznym znajdował się jednak pod wpływami Wielkiej Brytanii, a w latach 50. XX w. także Stanów Zjednoczonych. Sytuację tę zmienił przewrót antymonarchiczny, dokonany w lipcu 1958 r. przez oddziały armii irackiej dowodzone przez generała Abdula Karima al-Kasima. Krwawy zamach stanu, w trakcie którego

\footnotetext{
${ }^{3}$ Więcej na temat odłamów islamu zob. [w:] J. Danecki, Podstawowe wiadomości o islamie, t. 1-2, Warszawa 2002.

${ }^{4}$ W.L. Cleveland, A History of the Modern Middle East, Boulder 2000, s. 203.
} 
wymordowana została rodzina królewska oraz zginął ówczesny premier rządu irackiego, zapoczątkował rządy republikańskie. Republikański Irak w polityce zagranicznej przyjął zasadę neutralności wobec zimnowojennej konfrontacji amerykańsko-radzieckiej, jednak w wielu sytuacjach opowiadał się przeciwko polityce bliskowschodniej USA5 .

Wprowadzenie rządów republikańskich nie niosło ze sobą ustabilizowania sytemu politycznego. W kolejnych latach dochodziło do wstrząsów wewnętrznych i kolejnych zamachów stanu. Sytuacja wewnętrzna ustabilizowała się wraz z objęciem urzędu prezydenckiego przez Saddama Husajna w 1978 r. ${ }^{6}$ Nowy prezydent Iraku zdołał wprowadzić stabilny system rządów dyktatorskich, który zapewnił mu sprawowanie władzy aż do 2003 r. Upadek tego reżimu nie został jednak spowodowany pojawieniem się liczącej się opozycji wewnętrznej, lecz był efektem inwazji wojsk amerykańskich.

Okres rządów Saddama Husajna to także czas konfliktów zbrojnych, w które zaangażowało się to państwo. W latach 1980-1988 Irak stoczył krwawą wojnę z sąsiednim Iranem. W trakcie konfliktu obie zaangażowane strony straciły ponad milion żołnierzy. Samemu Irakowi wojna przyniosła także ogromne zadłużenie zewnętrzne, którego znaczna część pochodziła z pożyczek zaciągniętych w arabskich państwach Zatoki Perskiej, w tym z Kuwejtu.

W roku 1990 Saddam Husajn postanowił dokonać swoistej redukcji długów poprzez aneksję sąsiedniego państwa arabskiego - w sierpniu wojska irackie zajęły więc Kuwejt. W efekcie tych wydarzeń uformowała się międzynarodowa koalicja, pod przewodnictwem Stanów Zjednoczonych, której celem było doprowadzenie do oswobodzenia państwa kuwejckiego. Rysujące się zagrożenie, że Irak przejmie kontrolę nad większością zasobów ropy naftowej w regionie, było jedną z istotnych przyczyn podjęcia międzynarodowej operacji zbrojnej przeciwko Saddamowi Husajnowi ${ }^{7}$. Jeszcze w sierpniu 1990 r. Stany Zjednoczone rozpoczęly realizację operacji „Pustynna Tarcza”, w ramach której zaczęto przegrupowywać jednostki podległe amerykańskiemu Dowództwu Centralnemu na Bliskim Wschodzie (CENTCOM) i lokować je na terytorium Arabii Saudyjskiej. W styczniu 1991 r., działając w oparciu o rezolucje ONZ, wojska koalicji antyirackiej przystąpiły do operacji wyzwalania Kuwejtu.

Wojna zakończyła się klęską Iraku, nie doprowadziła jednak do upadku rządów Saddama Husajna. Antyrządowe powstania, jakie wywołali Kurdowie i szyici, zakończyły się porażką wobec braku poparcia sił koalicyjnych, których

\footnotetext{
${ }^{5}$ K. Czornik, Bliski Wschód w polityce zagranicznej Stanów Zjednoczonych w latach 1945-2012, Katowice 2012, s. 162 i nast.

${ }^{6}$ M. Barylew, Irak 2006-2012. Stabilizacja czy konflikt?, Toruń 2013, s. 13 i nast.

${ }^{7}$ S. Tanner, Wojny Bushów. Ojciec i syn jako zwierzchnicy sił zbrojnych, Wrocław 2007, s. 77.
} 
przywódcy uznali, że ich mandat nie obejmuje, poza wyzwoleniem Kuwejtu, operacji odsunięcia od władzy irackiego dyktatora. W tym czasie nie było chętnych, także po stronie USA, aby wziąć na siebie odpowiedzialność za sterowanie sytuacją wewnętrzną w Iraku'. W konsekwencji reżim Saddama Husajna przetrwał. Doszło przy tym do sytuacji, w której iracki prezydent stał się swoistym bohaterem dla antyzachodnich środowisk w państwach arabskich, jako przywódca, który rzucił wyzwanie Zachodowi, a mimo to zdołał się utrzymać przy władzy. W tym względzie sytuacja przypominała tę, która była udziałem innego z przywódców państw arabskich, a mianowicie - Gamala Abdel Nasera, który mimo klęski militarnej w wojnie z Izraelem i mocarstwami zachodnimi w 1956 r., umocnił swoją pozycję w świecie arabskim, jako ten, który przeciwstawiał się europejskiemu imperializmowi. Saddam Husajn w propagandzie politycznej wyraźnie odwoływał się zresztą do dziedzictwa egipskiego prezydenta, aspirując, podobnie jak on, do zdobycia dominującej pozycji w świecie arabskim?.

Po zakończonej wojnie o Kuwejt Irak pozostał osłabiony ekonomicznie i militarnie, do czego przyczyniły się również sankcje ekonomiczne narzucone przez Zachód. Pomimo systemu sankcji i polityki Stanów Zjednoczonych, Saddam zdołał utrzymać się przy władzy do początku pierwszej dekady XXI w. Bezpośrednią przyczyną upadku jego rządów stały się zamachy terrorystyczne na Stany Zjednoczone przeprowadzone przez Al-Kaidę.

Wkrótce po upadku rządu talibów w Afganistanie reżim Saddama Husajna stał się celem polityki amerykańskiej w regionie bliskowschodnim. W ramach tzw. doktryny Busha Irak został zaliczony, obok Iranu i Korei Północnej, do tzw. osi zła, czyli państw, które wspierają międzynarodowy terroryzm oraz dążą do proliferacji broni masowego rażenia. W roku 2002 zaczął narastać kryzys międzynarodowy, który ogniskował się wokół kwestii przyszłości reżimu Saddama Husajna. Prezydent USA George W. Bush ogłosił publicznie, że rozważa atak na Irak. Pretekstem miało być tu niewykonywanie rezolucji ONZ dotyczących likwidacji arsenału broni masowego rażenia oraz wspieranie międzynarodowego terroryzmu. Istotny asumpt do działań antyirackich dawała Stanom Zjednoczonym rezolucja Rady Bezpieczeństwa ONZ nr 1441, która zezwalała na zastosowanie odpowiednich środków, jeżeli reżim iracki będzie utrudniał działania inspektorów międzynarodowych szukających na terytorium irackim ewentualnych miejsc składowania i produkcji broni masowego rażenia ${ }^{10}$.

Pomimo międzynarodowego sprzeciwu wobec ewentualnej interwencji zbrojnej, administracja Busha juniora zdecydowała się na działanie. Siły koali-

${ }^{8}$ K. Czornik, Irak w polityce zagranicznej Stanów Zjednoczonych w okresie pozimnowojennym, Katowice 2011 , s. 145 i nast.

${ }^{9}$ R. Ruby, Saddam Hussein as Arab Hero: Following the Nasser Model WAR IN THE GULF, http://articles. baltimoresun.com/1991-02-10/news/1991041066_1_saddam-hussein-arab-nasser [dostęp 1.10.2015].

${ }^{10}$ Resolution 1441 (2002), United Nations Security Council, S/RES/1441 (2002), s. 1 i nast. 
cji międzynarodowej, której przewodziły Stany Zjednoczone, 20 marca 2003 r. rozpoczęly działania zbrojne przeciwko Irakowi w ramach operacji „Iracka Wolność". Oczywistym celem inwazji było odsunięcie od władzy Saddama Husajna. Działania zbrojne zostały zakończone wraz z zajęciem Bagdadu przez wojska amerykańskie 9 kwietnia 2003 r. Do rangi symbolu końca epoki saddamowskiej w dziejach Iraku urosło wkroczenie oddziałów wojskowych do Tikritu, miejsca narodzin irackiego dyktatora. Jego los dopełnił się w grudniu 2003 r., kiedy został schwytany przez żołnierzy amerykańskich w jednej ze swoich kryjówek, następnie oddany w ręce nowych władz irackich i stracony w wyniku procesu karnego. Prezydent Bush 1 maja 2003 r. ogłosił oficjalne zakończenie działań zbrojnych ${ }^{11}$. W czerwcu tego samego roku Irak został podzielony na strefy odpowiedzialności, z których jedna przypadła Polsce, jako państwu, które wzięło bezpośredni udział w działaniach wojennych. W ten sposób kraj ten znalazł się de facto pod okupacją międzynarodową.

O ile zwycięstwo w działaniach wojennych przyszło siłom amerykańskim stosunkowo łatwo, inaczej rzecz się miała z realizacją strategii powojennej. Po upadku rządów Saddama Husajna w Iraku zapanował chaos, na porządku dziennym były napady i rabunki. Podstawowym błędem popełnionym przez Amerykanów w opanowanym Iraku było zastosowanie strategii, która po II wojnie światowej odniosła sukces w Europie w odniesieniu do pokonanych Niemiec, ale nie sprawdziła się w przypadku państwa bliskowschodniego. Siły okupacyjne przystąpiły do likwidacji wszelkich pozostałości struktur władzy z okresu rządów Saddama Husajna. Pod hasłami debaasyfikacji pozbawiono pracy wszystkich członków byłej partii rządzącej, rozwiązano również resorty siłowe oraz zlikwidowano armię iracką. Efektem był narastający opór przeciwko wojskom koalicyjnym, powstanie partyzantki prosaddamowskiej, a także powołanie ugrupowań zbrojnych różnej proweniencji politycznej i religijnej, których celem stały się wojska koalicyjne oraz budowane w ramach tzw. działań stabilizacyjnych nowe struktury państwowe.

W lipcu 2003 r. USA powołały do życia Radę Zarządzającą na czele z Paulem Bremerem, której celem miało być zarządzanie krajem do czasu wyłonienia nowych władz irackich. Na mocy tymczasowej konstytucji Irak formalnie uzyskał suwerenność w czerwcu 2004 r. W tym czasie wyłoniono też tymczasowe władze państwowe, które miały sprawować rządy do czasu wyborów parlamentarnych. Powołanie tymczasowych struktur państwowych zakończyło oficjalnie okres okupacji terytorium Iraku, chociaż na mocy porozumienia z władzami irackimi wojska USA i innych państw koalicji antysaddamowskiej wciąż pozostawały w tym państwie. Pierwsze realne wybory powszechne odbyły się w Ira-

${ }^{11}$ K. Czornik, Irak w polityce zagranicznej Stanów Zjednoczonych..., s. 245. 
ku na początku stycznia 2005 r. W ich wyniku uformowały się nowe władze. Urząd prezydenta objął Kurd Dżalal Talabani, natomiast premierem rządu został szyita Nuri al-Maliki ${ }^{12}$.

Jak już wcześniej wspomniano, stałym elementem sytuacji wewnętrznej w Iraku w okresie postsaddamowskim stała się przemoc zbrojna. Kilka tygodni po zakończeniu działań wojennych uformowały się liczne oddziały rebelianckie, składające się z ludzi dawnego reżimu oraz pozbawionych pracy i stanowisk zdemobilizowanych oficerów i szeregowych żołnierzy armii irackiej. Podejmowali oni działania zbrojne zarówno przeciwko siłom okupacyjnym, jak i administracji nowo tworzonego państwa. Kolejnym elementem destabilizującym sytuację wewnętrzną był wybuch walk o charakterze religijnym pomiędzy sunnitami i szyitami, którego podłożem było oskarżanie tych ostatnich o kolaborację z siłami okupacyjnymi.

Ponieważ podstawę reżimu Saddama Husajna stanowili sunnici, Amerykanie uznali, że nowe struktury polityczne powinny być oparte o zwiększony udział szyitów, jako elementu większościowego w strukturze demograficznej państwa irackiego, a także wrogo nastawionego wobec dawnego reżimu i jego ludzi ${ }^{13}$. Postawienie na szyitów okazało się częściowo chybione. Przewagę zyskały wśród nich ugrupowania fundamentalistyczne, które zarówno były źródłem problemów dla władz koalicyjnych, jak i angażowały się w akty przemocy skierowane przeciwko ludności sunnickiej. Szczególnym paradoksem sytuacji wewnętrznej w Iraku, stało się to, że wojna prowadzona przeciwko Saddamowi $\mathrm{w}$ imię walki z międzynarodowym terroryzmem, w istocie stała się elementem jego promocji w samym Iraku, a także na Bliskim Wschodzie i w Europie. $\mathrm{Na}$ początku 2004 r. działalność w Iraku rozpoczęła Al-Kaida. Głównym koordynatorem i organizatorem działań irackiego odłamu tej organizacji został Jordańczyk Abu Musab az-Zarkawi ${ }^{14}$. Irak stal się polem bitwy dla wszystkich tych, którzy w imię prowadzenia dżihadu chcieli walczyć z żołnierzami amerykańskimi i koalicyjnymi. Działania terrorystyczne zostały przeniesione także na teren Europy - w marcu 2004 r. doszło do zamachu terrorystycznego w Madrycie, a rok później w Londynie. Jednym ze skutków tych działań było wycofanie żołnierzy hiszpańskich z misji stabilizacyjnej w Iraku ${ }^{15}$.

${ }^{12}$ Al-Maliki: From Popularity to Political Failure, http://www.mepc.org/articles-commentary/com mentary/malikis-actions-continue-antagonize-iraqi-sunnis?print [dostęp 1.10.2015].

${ }^{13}$ D. Filkinis, What We Left Behind. An Increasingly Authoritarian Leader, A Return of Sectarian Violence, And a Nation Worried for Its Future, http://www.newyorker.com/magazine/2014/04/28/whatwe-left-behind [dostęp 1.10.2015].

${ }^{14}$ The Crisis in Iraq. An Analysis of the Islamic State of Iraq and Levant (ISIS) with U.S. Policy. Recommendation in Iraq, UMAA-Advocasy Report Series, June 2014, s. 13.

${ }^{15}$ R. Machnikowski, Zamach w Madrycie 11 marca 2004 - wnioski dla Polski, http://www.specops. com.pl/CSiPS/artykuly_CSiPS/Doktor_Ryszard_Machnikowski/zamach\%20w\%20Madrycie.htm [dostęp 1.10.2015]. 
Sytuacja w Iraku zaczęła ulegać zmianie wraz z opracowaniem nowej strategii działań politycznych i militarnych przez wojska amerykańskie. W roku 2008 amerykański generał David Petraeus zaproponował nową strategię działań przeciwpartyzanckich. Polegała ona na czasowym zwiększeniu liczebności wojsk amerykańskich na terytorium irackim i zintensyfikowaniu operacji zbrojnych przeciwko ugrupowaniom partyzanckim i terrorystycznym. Natomiast drugim i, jak się miało okazać kluczowym posunięciem dla sukcesu tych działań, było uzyskanie poparcia ze strony ludności sunnickiej i lokalnych przywódców plemiennych na obszarach o największej aktywności ugrupowań zbrojnych. Na korzyść wojsk amerykańskich oddziaływała sytuacja wzrastających napięć pomiędzy ugrupowaniami terrorystycznymi a mającymi poparcie lokalnych struktur plemiennych organizacjami zbrojnymi, które sprzeciwiały się przede wszystkim wzrostowi znaczenia szyitów w strukturach politycznych nowego Iraku. Konflikt ten zarysował się szczególnie w prowincji Anbar, gdzie doszło do powstania tzw. ruchu przebudzenia, który zaczął występować przeciwko ugrupowaniom zbrojnym działającym w ramach irackiego odgałęzienia Al-Kaidy. Amerykanie doszli do porozumienia z lokalnymi przywódcami plemiennymi, rozpoczynając finansowanie lokalnych milicji, składających się z bojowników ugrupowań partyzanckich, którzy w tym momencie wystąpili przeciwko ugrupowaniom powiązanym z Al-Kaidą. Inną przyczyną wolty wykonanej przez sunnitów były obietnice związane z uwzględnieniem ich w strukturach nowego państwa ${ }^{16}$.

W efekcie nowy amerykański prezydent Barack Obama, dążący do poprawy wizerunku USA w świecie arabskim, mógł ogłosić w roku 2011, że wraz z ograniczeniem działań ugrupowań zbrojnych, plan wycofania żołnierzy amerykańskich z terytorium irackiego, uzgodniony z rządem premiera Nuriego al-Malikiego w 2008 r., jest całkiem prawdopodobny. Deklaracja została wkrótce zrealizowana - z końcem 2011 r. żołnierze amerykańscy opuścili Irak. Bilans konfliktu okazał się jednak tragiczny. W ramach działań stabilizacyjnych zginęło około 5000 żołnierzy wojsk koalicyjnych, w tym 4400 żołnierzy amerykańskich ${ }^{17}$. Przy czym są to straty poniesione już po zakończeniu działań zbrojnych, a więc od maja 2003 r. Jeszcze tragiczniej sytuacja wygląda z punktu widzenia Iraku. W wyniku działań zbrojnych skierowanych przeciwko koalicji oraz walk wewnętrznych śmierć poniosło ponad 800 tys. Irakijczyków ${ }^{18}$.

Sytuacja wewnętrzna w Iraku na przełomie pierwszej i drugiej dekady XXI w. zdawała się nieść nadzieję na zakończenie aktów przemocy. Tak się jednak nie stało,

\footnotetext{
${ }^{16}$ M. Wilbank, E. Karsh, How the „Sons of Iraq” Stabilized Iraq, „Middle East Qarterly” 2010, Vol. 17, No. 4, http://www.meforum.org/2788/sons-of-iraq [dostęp 1.10.2015].

${ }^{17}$ M. Zawadzki, Bilans Iraku, http://wyborcza.pl/1,76842,10833469,Bilans_Iraku.html [dostęp 1.10.2015].

${ }^{18}$ Ibidem.
} 
na co złożyło się wiele przyczyn. Początkowo uwaga międzynarodowej opinii publicznej została skierowana na inne regiony Bliskiego Wschodu w związku z rozwojem wydarzeń w ramach tzw. Arabskiej Wiosny. Jednak na początku 2014 r. sytuacja w Iraku ponownie przyciągnęła uwagę nie tylko opinii publicznej, ale również polityków regionalnych i międzynarodowych, za sprawą działalności jednej z organizacji terrorystycznych pod nazwą Irackie Państwo Iraku i Lewantu/Syrii (ISIS) ${ }^{19}$.

W roku 2013 organizacja ta zdołała przejąć kontrolę nad centralnymi i wschodnimi obszarami Syrii, a z początkiem 2014 r. przeniosła swoją działalność na terytorium Iraku. Dużym zaskoczeniem dla społeczności międzynarodowej stały się sukcesy ISIS związane z opanowaniem niemal polowy terytorium irackiego. Najbardziej spektakularnym posunięciem tej organizacji było zdobycie Mosulu oraz przejecie kontroli nad sunnickimi prowincjami środkowego i północnego Iraku - Anbarem, Niniwą, Salah ad-Din. Oddziały ISIS zagroziły również stolicy Iraku - Bagdadowi. Jednocześnie nie ustały operacje zbrojne na terytorium syryjskim. Powszechną uwagę przyciągają wciąż trwające walki o kurdyjskie miasto Kobane na pograniczu turecko-syryjskim. Sukcesy militarne ISIS spowodowały, że organizacja ta została uznana przez wiele państw, zarówno z Bliskiego Wschodu, jak i spoza tego obszaru, za najistotniejsze zagrożenie dla bezpieczeństwa regionu. W efekcie takiego rozwoju wydarzeń uformowała się międzynarodowa koalicja, której działania obejmują m.in. prowadzenie ataków powietrznych skierowanych przeciwko oddziałom ISIS.

Za szczególne uzasadnienie operacji militarnych skierowanych przeciwko tzw. Państwu Islamskiemu uznaje się popełnianie przez jej członków zbrodni na ludności cywilnej. Znamienne jest, że ISIS, prowadząc operacje militarne, nie jest typową organizacją terrorystyczną ukierunkowaną na stosowanie przemocy wobec wybranych celów cywilnych lub militarnych. Zawarte w nazwie organizacji odwołanie do stworzenia struktury politycznej w postaci państwa nie okazało się zabiegiem jedynie semantycznym - 29 czerwca 2014 r. ISIS ogłosiło utworzenie na kontrolowanych przez siebie obszarach tzw. Państwa Islamskiego $^{20}$. Na jego czele stanął przywódca organizacji Abu Bakr al-Baghdadi. Jednocześnie został on ogłoszony kalifem i imamem, roszcząc sobie przy tym prawo do przewodzenia wszystkim muzułmanom na świecie. W ten sposób nie tylko zostało rzucone poważne wyzwanie dla porządku terytorialnego na Bliskim Wschodzie, ale również rozpoczęto nowy etap walki o „serca i umysły” samych muzułmanów. Deklaracja o odnowieniu instytucji imamatu i kalifatu jest wy-

\footnotetext{
${ }^{19}$ Nazwa organizacji w języku arabskim - Ad-Dbaula al-Islamija fi-l-Irak wa-sz-Szam. Asz-Szam ma kilka znaczeń, m.in. Syria, Lewant. Z tego powodu dalej w tekście - jako najbardziej rozpowszechniony - będzie stosowany skrót ISIS.

${ }^{20}$ D. Milton, B. Price, M. al-'Ubaydi, The Islamic State in Iraq and Levant: More than Just a June Surprise, „CTC SRNYINEL” 2004, Vol. 7, Issue 6, s. 1.
} 
raźnym wyzwaniem rzuconym przywództwu politycznemu i religijnemu domu Saudów, jako powiernikowi świętych miejsc islamu - Mekki i Medyny. Sukcesy, jakie są udziałem ISIS, rodzą liczne pytania dotyczące ich źródeł, modelu ustrojowego, jaki stara się przyjąć nowe państwo, oraz możliwości jego przetrwania i rozwoju. Przy czym ta ostatnia kwestia dotyczy także trwałości całego ładu politycznego i terytorialnego na Bliskim Wschodzie. Jeśli nawet samo „Państwo Islamskie" nie przetrwa, co wcale nie jest takie pewne, to jego pojawienie się może stanowić czynnik inicjujący istotne zmiany na mapie politycznej regionu.

ISIS nie jest aż tak nową siłą polityczną, jak mogłoby się pozornie wydawać. Powstanie i rozwój tej organizacji związane są z pojawieniem się z końcem lat 90. XX w. kilku nowych organizacji terrorystycznych na Bliskim Wschodzie, motywowanych religijnie i podejmujących działania skierowane przeciwko regionalnej dominacji Stanów Zjednoczonych. Istotnym czynnikiem przyśpieszającym rozwój takich struktur stała się amerykańska inwazja na Irak i okupacja tego kraju. Geneza ISIS jest związana z działalnością Abu Musy az-Zarkawiego.

W 2004 r. grupa Zarkawiego działająca w Iraku przyjęła nazwę Organizacja Monoteizmu i Dżihadu, a następnie - Al-Kaida Obszaru Mezopotamii ${ }^{21}$. Stała się jednym z najbardziej aktywnych ugrupowań bojowych w Iraku działających w ramach struktur dżihadystycznych tworzonych pod szyldem Al-Kaidy (bardziej była znana pod skróconą nazwą - Al-Kaida Iraku). Strategia walki przyjęta przez Zarkawiego zakładała wielopłaszczyznowe destabilizowanie sytuacji wewnętrznej w Iraku. Jej działania nie były skierowane jedynie przeciwko wojskom okupacyjnym. Celem ataków, których arsenał obejmował zamachy bombowe, zabójstwa polityczne czy szczególnie okrutne egzekucje osób cywilnych, przede wszystkim pracowników instytucji międzynarodowych zaangażowanych w odbudowę infrastruktury państwowej, stali się nie tylko przedstawiciele nowych władz państwowych i administracji lokalnej. Grupa Zarkawiego odpowiedzialna była również za ataki przeciwko ludności szyickiej ${ }^{22}$. Tym samym taktyka działań destabilizujących obejmowała także wywołanie konfliktu o charakterze religijnym pomiędzy sunnitami a szyitami.

Sposób i zakres działań irackiej Al-Kaidy pod przywództwem Zarkawiego sprawił, że stał się on najbardziej poszukiwaną osobą na terytorium irackim przez siły koalicyjne. Na początku 2006 r. doprowadził do zawiązania sojuszu pomiędzy Al-Kaidą i mniejszymi ugrupowaniami zbrojnymi. W ten sposób powstała Rada Mudżahedinów. W lipcu 2006 r. wojska amerykańskie zabiły

${ }^{21}$ C. Acun, Neo al Qaueda: The Islamic State of Iraq and the Sham (ISIS), „SETA Perspective” 2014, No. 10 , s. 2.

${ }^{22}$ E. Hunt, Zarqawis "Total War” on Iraqi Shiites Exposes a Divide among Sunni Jihadists, http:// www.washingtoninstitute.org/policy-analysis/view/zarqawis-total-war-on-iraqi-shiites-exposes-a-divideamong-sunni-jihadists [dostęp 1.10.2015]. 
Zarkawiego, a jego następcą został Egipcjanin Abu Ajub al-Masri ${ }^{23}$. To z jego inicjatywy organizacja przyjęła nową nazwę - Islamskie Państwo Iraku. Celem zmiany było zwiększenie powiązania organizacji z obszarem jej działania, a tym samym uzyskanie akceptacji ze strony irackich sunnitów, dla których organizacja stawała się problematyczna do zaakceptowania ze względu na liczny udział bojowników pochodzących z innych krajów arabskich i muzułmańskich.

Dla dalszego rozwoju organizacji kluczowe stały się wydarzenia z 2010 r., kiedy w amerykańskich atakach rakietowych zginęli jej ówcześni przywódcy. Rada Mudżaheddinów na nowego lidera wybrała Abu Bakra al-Baghdadiego $^{24}$. Urodzony w sunnickiej rodzinie w 1971 r. w irackiej Samarze, był członkiem jednej z irackich radykalnych organizacji bojowych. W roku 2004 został schwytany przez siły koalicyjne i uwięziony. W 2009 r. został zwolniony z więzienia wraz z grupą innych członków sunnickich organizacji zbrojnych. Po przejęciu dowództwa nad organizacją Baghdadi dokonał kolejnej zmiany jej nazwy. Od 2013 r. stała się znana jako Islamskie Państwo Iraku i Lewantu. W ten sposób Baghdadi wskazywał, jaki powinien być obszar działania dowodzonej przez niego organizacji ${ }^{25}$.

Czynnikiem, który umożliwił przegrupowanie i rozwój organizacji, stał się wybuch i rozwój wojny domowej w Syrii po 2011 r. ${ }^{26}$ Zarówno Stany Zjednoczone, jak i państwa regionu - Arabia Saudyjska i Katar rozpoczęły wspieranie ugrupowań walczących z wojskami lojalnymi wobec prezydenta Baszszara Asada. O ile pomoc USA, przynajmniej oficjalnie, miała charakter humanitarny, obejmowała także przekazywanie środków finansowych i wyposażenia technicznego o charakterze militarnym, głównie Wolnej Armii Syrii, to w przypadku wspomnianych państw bliskowschodnich rzecz miała się zgoła inaczej. Arabia Saudyjska, a jeszcze w większej mierze Katar, zaangażowały się we wspieranie grup zbrojnych o charakterze fundamentalistycznym. Pomoc ta obejmowała również przekazywanie uzbrojenia. Państwa Zatoki sfinansowały dostawy broni z obszaru Chorwacji. Tysiące sztuk broni miało dotrzeć do opozycji syryjskiej w grudniu 2012 r. Nie można wykluczyć, że część uzbrojenia trafiła w ręce różnych grup dżihadystycznych, w tym ISIS, wyraźnie wzmacniając jego możliwości militarne. Nie jest do końca pewne, jaką siłą zbrojną dysponowała ta organizacja. Według niepotwierdzonych danych, ISIS miało liczyć 10 tys. bojowników, co w warunkach syryjskich stanowiło istotną siłę. W tym

\footnotetext{
${ }^{23}$ Z.K. Gulmohad, The Rise and Fall of the Islamic State of Iraq and Al-Sham (Levant) ISIS, „Global Security Studies" 2014, Vol. 5, Issue 2, s. 1.

${ }^{24}$ Ibidem.

${ }^{25}$ J.A. Sekulov, R. Weston, The Dangerous ISIS and Its Progeny Pose to Regional and Global Peace, http:// oxfordpolicycentre.org/research-papers/20141012\%20ISIS\%20Paper\%20FINAL.pdf, s. 2 [dostęp 1.10.2015].

${ }^{26}$ C. Acun, op. cit., s. 3.
} 
czasie Baghdadi oficjalnie przedstawił program budowy państwa muzułmańskiego opartego na rygorystycznej doktrynie szariatu. Na tym gruncie doszło do zaostrzenia konfliktu pomiędzy ISIS a pozostałymi grupami zbrojnymi opozycji antyasadowskiej ${ }^{27}$. Od końca 2013 r. dochodziło już do regularnych starć zbrojnych pomiędzy oddziałami Wolnej Armii Syrii a oddziałami ISIS. Przeciwko Baghdadiemu zaczęły występować również pomniejsze organizacje dżihadystyczne. Została zerwana współpraca pomiędzy ISIS a Frontem an-Nusra, gdy Baghdadi ogłosił podporządkowanie Frontu swojej organizacji ${ }^{28}$.

Główną podstawą działań przeciwko ISIS podejmowanych przez inne syryjskie organizacje zbrojne było prowadzenie przez tę organizację akcji skierowanych nie tylko przeciwko siłom rządowym. Jest ona odpowiedzialna za czystki etniczne dokonywane na alawitach, szyitach, jazydach, Kurdach, a także umiarkowanych sunnitach ${ }^{29}$. Na początku 2014 r. ISIS straciło także poparcie Al-Kaidy. Przy czym nie był to efekt sprzeciwu wobec form i zakresu jego działania, lecz wynik ignorowania przez przywództwo poleceń Ajmana az-Zawahiriego, który przyjął kierowanie Al-Kaidą po śmierci Usamy Ibn Ladina w 2011 r. W maju 2013 r. Zawahiri nakazał ISIS, aby zaprzestało działań zmierzających do podporządkowania sobie Frontu an-Nusra, uznawanego za oficjalnego przedstawiciela Al-Kaidy na terenie Syrii. Próba rozciągnięcia kontroli nad Frontem, podjęta przez Baghdadiego, doprowadziła do ostatecznego zerwania pomiędzy dwoma organizacjami ${ }^{30}$.

Szczególnie ciężkie walki na terenie Syrii toczyły się o kontrolę nad Aleppo oraz tereny muhtafazy Ar-Rakka i Hama pomiędzy styczniem a kwietniem 2014 r. W wyniku działań nieformalnego sojuszu syryjskich organizacji zbrojnych oddziały ISIS nie zdołały w pełni opanować wymienionych obszarów. Wciąż jednak pod kontrolą dżihadystów z ISIS pozostają centralne i wschodnie obszary Syrii, pogranicze irackie, a także blisko połowa linii granicznej z Turcją. Pomimo porażek, jakie towarzyszyły działaniom ISIS w Syrii, organizacja ta podjęła ofensywę militarną na obszarze Iraku. Jak już wspomniano, w trakcie zaledwie kilku tygodni udało się jej nie tylko przenieść poważne operacje zbrojne na teren sąsiedniego Iraku, ale opanować najważniejsze prowincje w środkowej i północnej części kraju, a także zająć Mosul na pograniczu obszaru zamieszkanego przez Kurdów.

Rodzi się zatem pytanie o pochodzenie siły i źródeł sukcesów organizacji. Istotną kwestią jest to, jak doszło do tego, że w stosunkowo krótkim czasie bo-

\footnotetext{
${ }^{27}$ D. Milton, B. Price, M. al-Ubaydi, op. cit., s. 2.

${ }^{28}$ Ibidem.

${ }^{29}$ Zob.: Amnesty International Briefing, 19.12.2013, http://www.countercurrents.org/amnesty 201213.pdf [dostęp 1.10.2015].

${ }^{30}$ J.A. Sekulow, R. Weston, op. cit., s. 5.
} 
jownicy ISIS zdołali odnieść tak poważne sukcesy na terytorium irackim. W tym względzie należy niewątpliwie wziąć pod uwagę relacje sunnicko-szyickie.

Począwszy od 2006 r. urząd premiera Iraku sprawował nieprzerwanie szyita Nuri al-Maliki ${ }^{31}$. Jego rząd miał za sobą poparcie Stanów Zjednoczonych, co było częścią amerykańskiej strategii ograniczania wpływów irańskich wśród irackich szyitów. Administracja waszyngtońska uznała, że oparcie struktur władzy nowego państwa irackiego na politykach szyickich ograniczy działalność szyickich milicji zbrojnych, szczególnie tych subsydiowanych przez Iran, atakujących nie tylko sunnitów, ale także wojska okupacyjne. O ile amerykańska zgoda na utworzenie gabinetu z szyickim premierem, a następnie popieranie go, doprowadziła do ograniczenia działalności zbrojnej milicji szyickich, to faworyzowanie grupy ludności kosztem sunnitów powodowało kontynuowanie oporu zbrojnego przez sunnickich insurgentów. Dopiero wprowadzenie strategii działań przeciwpartyzanckich generała Petraeusa, której istotnym elementem był kompromis sunnicko-szyicki, zawierający obietnicę włączenia sunnitów w struktury nowego państwa, pozwoliło na ograniczenie aktów przemocy w Iraku.

Sytuacja uległa zmianie po wycofaniu sil amerykańskich w 2011 r. W Iraku ponownie zaczął narastać kryzys polityczny, spowodowany polityką wewnętrzną premiera Malikiego. Sunnici zaczęli oskarżać jego rząd o działania autorytarne. Nierozwiązane pozostały kwestie ekonomiczno-polityczne, takie jak nierównomierny podział zysków z eksploatacji pól naftowych, brak dostępu do urzędów centralnych i lokalnych, a wreszcie wszechobecna korupcja. Rosnące niezadowolenie z rządów Malikiego spowodowało wznowienie działań zbrojnych przez ugrupowania sunnickie ${ }^{32}$. ISIS wykorzystało więc kryzys wewnętrzny w Iraku oraz rozwijającą się kolejną rebelię sunnicką do podjęcia próby opanowania nowych terytoriów. W ten sposób przywództwo organizacji pokazało, że zna uwarunkowania społeczne i polityczne na obszarze, który jest docelowym miejscem jej działań, a tym samym posiada zdolność wykorzystania sytuacji, gdy istnieją sprzyjające ku temu okoliczności.

Kolejną kwestią, która wydaje się kluczowa dla zrozumienia źródeł siły ISIS, jest fakt, że organizacja ta dysponuje dobrze zorganizowanym przywództwem, zdolnym wyciągać wnioski z wcześniejszych niepowodzeń oraz skutecznie dostosowywać strategię działań do zmieniających się okoliczności. Jednak jednym z najważniejszych czynników umożliwiających funkcjonowanie organizacji jest zinstytucjonalizowana ekonomia wojenna. Pod rządami Baghdadiego zdołała ona wypracować poważne źródła pozyskiwania dochodów niezbędnych dla pro-

\footnotetext{
${ }^{31}$ Al-Maliki...

${ }^{32}$ Ibidem. W dniu 8 sierpnia 2014 r. został utworzony nowy gabinet z Haiderem al-Abadim jako premierem (M. Madi, Haider al-Abadi: A New Era for Iraq?, http://www.bbc.com/news/world-middleeast-28748366 [dostęp 1.10.2015]).
} 
wadzenia nie ataków terrorystycznych, lecz regularnych działań zbrojnych, których celem jest zdobycie terytorium i sprawowanie nad nim stałej kontroli, aż do stworzenia realnych struktur państwowych.

W początkowym okresie działalności ISIS głównym źródłem finansowania operacji wojennych były dotacje ze strony bogatych donatorów pochodzących z arabskich państw Zatoki Perskiej. Innym źródłem finansowania działalności ISIS na terenie Syrii mogły być subsydia, które Katar i Arabia Syryjska przekazywały organizacjom o profilu religijnym. Nie można wykluczyć, że część tych środków finansowych trafiła do ISIS, a zatem pośrednio również państwa Zatoki mogły przyczynić się do wzmocnienia organizacji ${ }^{33}$. Jednak to ona sama w największym stopniu zdołała wypracować własną ekonomię wojenną, która pozwoliła na zakup uzbrojenia, finansowanie bojowników, a także rekrutację nowych, w tym na obszarze państw Unii Europejskiej.

Wzorzec finansowania działań zbrojnych został wypracowany na początku 2013 r. Jednym z istotnych źródeł finansowania działań ISIS jest eksploatacja i nielegalna sprzedaż ropy naftowej. Szacunkowe wydobycie i rafinacja ropy naftowej na terenach zajętych przez bojowników wynosi około 9 tys. baryłek ropy naftowej dziennie. ISIS zdołało przejąć ważne elementy infrastruktury wykorzystywanej do produkcji ropy naftowej, zarówno na terenie Syrii, jak i Iraku. Kontrola nad granicą z Turcją daje organizacji możliwość nielegalnego transportowania tego surowca przez jej terytorium. Szacunkowe dane wskazują na to, że tzw. Państwo Islamskie otrzymuje $1 \mathrm{mln}$ USD dziennie ze sprzedaży ropy naftowej do państw ościennych ${ }^{34}$. Innym źródłem dochodów ISIS jest nielegalny handel starożytnościami. Zasoby finansowe, którymi organizacja dysponowała na koniec 2013 r., szacowano na 875 mln dolarów. Uległy one dalszemu powiększeniu wraz z zajęciem instytucji bankowych w miastach irackich. Szacuje się, że zajęcie zasobów bankowych w Mosulu dało organizacji kolejne $430 \mathrm{mln}$ dolarów ${ }^{35}$. Równocześnie przejęcie broni zgromadzonej w magazynach wojskowych armii irackiej wyraźnie zwiększyło jej zdolność bojową.

ISIS, stosując zasady nowej ekonomii wojennej, praktykowanej we współczesnych konfliktach zbrojnych, osiągnęło znaczne możliwości samofinansowania. Oznacza to, że instrument walki z podobnymi ugrupowaniami, jakim jest pozbawianie ich możliwości finansowania dalszych operacji poprzez odcięcie

${ }^{33}$ Kto finansuje terrorystów z Państwa Islamskiego, http://www.se.pl/pieniadze/newsy/kto-finansujeterrorystow-z-panstwa-islamskiego_729242.html [dostęp 21.11.2015].

${ }^{34}$ M. Połoński, ISIS zmienia geopolitykę Bliskiego Wschodu, http://www.defence24.pl/117153, isiszmienia-geopolityke-bliskiego-wschodu [dostęp 1.10.2015].

${ }^{35}$ D. Płatek, Mobilizacja zasobów Państwa Islamskiego w Iraku i Lewancie, https://www.academia. edu/10193757/MOBILIZACJA_ZASOB\%C3\%93W_PA\%C5\%83STWA_ISLAMSKIEGO_W_ IRAKU_I_LEWANCIE, s. 12 [dostęp 1.10.2015]. 
od źródeł dopływu środków finansowych, będzie trudny w zastosowaniu i niekoniecznie może przynieść spodziewany efekt.

Kolejnym ważnym elementem związanym z działalnością ISIS jest wspomniane już ogłoszenie powstania nowej struktury politycznej, tzw. Państwa Islamskiego, na terenach znajdujących się pod kontrolą bojowników. Samego Abu Bakra al-Baghdadiego, przyjmującego przy okazji imię Ibrahima, ogłoszono imamem i kalifem, a tym samym przywódcą nie tylko Arabów, ale wszystkich wyznawców Allaha na całym świecie ${ }^{36}$. Deklaracja ta wskazywała również, że nowy kalif jest „potomkiem z rodu Proroka” ${ }^{37}$. ISIS odwołuje się tym samym do fundamentalistycznej koncepcji odbudowy kalifatu jako struktury, w ramach której powinno być realizowane życie polityczne. Idea kalifatu jest głęboko zakorzeniona przede wszystkim w kręgu arabsko-muzułmańskim. W wymiarze współczesnym koncepcja ta jest w największym stopniu kojarzona ze zjawiskiem muzułmańskiego fundamentalizmu. Muzułmanie uznają, że islam jest uniwersalną religią, która dotyka każdego aspektu życia wyznawcy Allaha oraz społeczności - ummy, jaką wszyscy oni tworzą. Ważnym aspektem całej koncepcji jest wszechogarniający charakter religii, która nie widzi podziału na sacrum i profanum także w świecie polityki. Islam jest jednocześnie religią, systemem wierzeń, wzorcem zachowań i reguł, które odnoszą się również do świata polityki. Krytycy koncepcji fundamentalizmu muzułmańskiego, traktowanego nie tylko jako ruch odnowy religijnej, posługują się argumentem, że w ten sposób dochodzi do polityzacji religii, powstania politycznego islamu. Jest to argument w dużej mierze chybiony, zważywszy na fakt, że rozdzielenie w islamie tego, co prywatne w praktykowaniu religii, od tego, co publiczne, jest praktycznie niemożliwe. W istocie islam zawsze był i pozostanie polityczny. Wielkie koncepcje filozoficzne świata islamu brały pod uwagę nie tylko dogmaty religijne, ale również analizowały powiązania pomiędzy religią a pochodzeniem władzy i jej sprawowaniem nad umma. Także we współczesnym świecie arabskim można dostrzec ważną korelację pomiędzy islamem i władzą polityczną. Wszystkie kraje arabskie deklarują ją w swoich konstytucjach, tam gdzie one istnieją, a tam gdzie nie zostały one spisane, następuje to w formie ustaw najwyższego rzędu.

Konstytucje państw arabskich określają islam jako religię państwową, a szariat traktują jako jedno ze źródeł prawa. Kalif, czyli zastępca Boga na ziemi, był nie tylko przywódcą politycznym, ale i najwyższym autorytetem religijnym, odpowiedzialnym również za realizację boskiego porządku prawnego.

${ }^{36}$ The Rise of the New „Caliph”, ISIS Chief Abu Bakr al-Baghdadi, http://english.alarabiya.net/en/ perspective/profiles/2014/06/30/The-rise-of-the-new-caliph-ISIS-chief-Abu-Bakr-al-Baghdadi.html [dostęp 1.10.2015].

${ }^{37}$ A.Y. Zelin, Abu Bakr al-Baghdadi: Islamic State's Driving Force, http://www.bbc.com/news/worldmiddle-east-28560449 [dostęp 1.10.2015]. 
Jest to przy tym odwołanie się do okresu klasycznego państwa muzułmańskiego, w którym rządy sprawował prorok Muhammad oraz jego czterej kolejni następcy - nazywani kalifami sprawiedliwymi. W kolejnych stuleciach instytucja kalifatu przechodziła różne wstrząsy. W kręgu arabsko-muzułmańskim pozostawała praktykowana w ramach rządów dynastii Ummajadów i Abbasydów. Wreszcie instytucja ta została złączona z sułtanami osmańskimi. Kalifat został rozwiązany przez tureckie Zgromadzenie Narodowe z inicjatywy Kemala Paszy Atatürka w roku 1924. Od tego czasu wezwanie do odtworzenia kalifatu stało się naczelnym hasłem różnych ugrupowań fundamentalistycznych - począwszy od Braci Muzułmanów, na Al-Kaidzie kończąc ${ }^{38}$.

Dla wielu współczesnych muzułmanów instytucja kalifatu pozostaje symbolem dawnej świetności, skuteczności i sprawiedliwości państwa muzułmańskiego. Jest to symbol, który rodzi po ich stronie jak najbardziej pozytywne konotacje. Należy podkreślić, że żadne z ugrupowań fundamentalistycznych (poza Boko Haram w Nigerii) nie odważyło się zadeklarować odbudowy kalifatu i ogłoszenia kalifem swego przywódcy. Uczynił to jedynie ISIS, przy czym nie chodzi tylko o samą instytucję. Mamy zatem do czynienia z hierarchiczną strukturą organów państwowych, na którą składają się również inne instytucje, tworzące cały aparat rządowy tzw. Państwa Islamskiego ${ }^{39}$. Możemy tu wymienić chociażby: Radę Szariatu, Radę Ummy, Radę Wojskową, Radę Bezpieczeństwa. Tzw. Państwo Islamskie przekształca także dotychczasowe struktury administracji terytorialnej, tworząc własne prowincje - wilajety ${ }^{40}$. Na podstawie realnych działań można powiedzieć, że tzw. Państwo Islamskie rzeczywiście spełnia warunki konieczne do tego, aby konkretną jednostkę polityczną nazwać państwem - posiada rząd, ludność i kontroluje dane terytorium. Ostatni warunek nie jest jednak do końca spełniony, gdyż w pełni nie wyznaczono jeszcze zasięgu terytorium ${ }^{41}$.

Powyższa sytuacja ukazuje rzeczywiste intencje ruchu. Celem ISIS jest bowiem utworzenie państwa i de facto jest to czynione. Kiedy organizacja zajmowała irackie miasta, pojawiły się opinie, że posługując się okrucieństwem, wprowadzając drakońskie prawa, piętnując innowierców, każąc im płacić podatki na rzecz ummy, doprowadzi do buntu lokalnej ludności i nie będzie w stanie sprawnie rządzić. Obecnie jednak właśnie to robi. Jak na razie, nie docho-

\footnotetext{
${ }^{38}$ Więcej na temat instytucji kalifatu i jego znaczenia w świecie arabsko-muzułmańskim zob. [w:] K. Czajkowska, A. Diawoł-Sitko, Systemy polityczne w wybranych pañstwach Bliskiego Wschodu, Warszawa 2012, s. 62 i nast.

${ }^{39}$ I. Neriah, The Structure of the Islamic State (ISIS), http://www.jcpa.org/structure-of-the-islamic/ state [dostęp 1.10.2015].

${ }^{40}$ Th. Karosik, ISIS Continues Its State-Building Project Unabaled, http://english-alarabija.net/en/views/ news/middle-east/2014/11/23/ISIS-continues-its-state-building-project-unabaled.htlm [dostęp 1.10.2015].

${ }^{41} \mathrm{M}$. Wachnicki, Jak wyglada struktura organizacyjna Państwa Islamskiego? „Ma wiele elementów totalitaryzmu”, http://wyborcza.pl/1,76842,16899161,Jak_wyglada_struktura_organizacyjna_Panstwa_ Islamskiego_html\#ixzz3tULYAm9B [dostęp 1.10.2015].
} 
dzą do nas żadne informacje o buntach przeciwko tzw. Państwu Islamskiemu. Bez wątpienia jest to efekt stosowania przemocy politycznej, fizycznego likwidowania tych, którzy mogą stanowić przyszłe zagrożenie dla nowej władzy. Za przykład może posłużyć zamordowanie kilkudziesięciu członków plemienia Albu Nimr w irackiej prowincji Anbar, które wystąpiło przeciwko irackiej Al-Kaidzie w 2008 r. W ten sposób dokonano nie tylko zemsty na dawnych wrogach, ale przede wszystkim spacyfikowano ewentualnych oponentów.

Należy przy tym podkreślić, że ISIS to nie tylko bezwzględna przemoc. Na obszarach kontrolowanych przez „Państwo Islamskie” działają sklepy, szkoły czy inne instytucje, zakładane są oddziały policji obyczajowej, bezproblemowo działa infrastruktura miejska. Wreszcie „państwo” zapewnia realizację pomocy charytatywnej dla osób ubogich. Podejmowany jest zatem konkretny wysiłek, który ma świadczyć o tym, że bojownicy ISIS to nie tylko bezwzględni terroryści, ale przede wszystkim muzułmanie, którzy tworzą własne państwo. Dżihadyści z ISIS pokazują, że potrafią rządzić, szczególnie w porównaniu z niewydolnością wcześniejszej administracji państwa irackiego, a to przynosi efekt w postaci akceptacji ze strony irackich sunnitów.

Kolejnym zagadnieniem, które wiąże się z kwestią budowania struktur państwowych, co również zapewnia tzw. Państwu Islamskiemu poparcie ze strony wielu muzułmanów, jest redefiniowanie bliskowschodniego porządku terytorialnego. Organizacja tworzy nową strukturę polityczną, której celem jest dalsza ekspansja. Tym samym ukazuje swój sprzeciw wobec porządku terytorialnego narzuconego, zdaniem fundamentalistów, jedynie przez Zachód. Należy bowiem pamiętać o powszechnym na Bliskim Wschodzie przekonaniu, że to mocarstwa zachodnie są odpowiedzialne za utworzenie systemu politycznego całego regionu. W ich opinii powstał on po to, aby zabezpieczyć interesy Zachodu, a nie muzułmanów. Antyzachodnie, a przede wszystkim antyamerykańskie resentymenty są wykorzystywanie w propagandzie ISIS i przynoszą mu spore poparcie ${ }^{42}$.

Powstanie ISIS, a następnie proklamowanie przez nie tzw. Państwa Islamskiego w 2014 r. stanowi bardzo poważne zagrożenie dla regionalnego porządku politycznego. Dzieje się tak jednak nie dlatego, iż jest to szczególnie okrutna organizacja, ale że rzuca ona wyzwanie całemu porządkowi politycznemu. Ostateczny kształt terytorialny tzw. Państwa Islamskiego nie został jeszcze ustalony. Ambicje Baghdadiego jako kalifa sięgają Mekki i Medyny, a to stwarza bezpośrednie zagrożenie dla Arabii Saudyjskiej. ISIS podejmuje już działania w Libanie, może również uzyskać akceptację ze strony organizacji jemeńskich, które działają w ramach siatki Al-Kaidy Półwyspu Arabskiego. Jego sukcesy

${ }^{42}$ J.T. Gordon, ISIS' Desire to Erase Sykes-Picot Is Rooted in Fiction, Not History, http://nationalinterest. org/feature/isis\%E2\%80\%99-desire-erase-sykes-picot-rooted-fiction-not-history-11293 [dostęp 1.10.2015]. 
czynią go jeszcze bardziej atrakcyjnym dla wielu organizacji dżihadystycznych, co może skłonić je do wsparcia tej organizacji i zerwania powiązań z Al-Kaidą.

Należy stwierdzić, że powstanie ISIS, a następnie tzw. Państwa Islamskiego, to efekt nałożenia się na siebie wielu czynników. Jednym z nich jest ukształtowanie się na Bliskim Wschodzie ideologii fundamentalistycznej, wrogiej Zachodowi i oskarżającej go o wszelkie problemy i nierówności, jakie są udziałem muzułmanów. Jest to również ideologia wroga współczesnym strukturom politycznym świata arabskiego, jako akceptującym dominację Zachodu. Kolejnym czynnikiem jest radykalizacja nastrojów politycznych, związana z amerykańskimi operacjami wojskowymi w obszarze Zatoki, podkreślającymi przekonanie fundamentalistów o negatywnej roli Zachodu w polityce bliskowschodniej. Innym elementem są wydarzenia Arabskiej Wiosny, w czasie której Zachód, USA czy wreszcie lokalne państwa arabskie przyjęły realizację polityki, która sama generowała dalsze problemy w państwach bliskowschodnich. Gdy rozpoczęła się wojna domowa w Syrii, zaczęto wspierać rebeliantów, nie biorąc pod uwagę, jakie to może przynieść konsekwencje dla całego regionu. Warto przy tym podkreślić niezdolność społeczności międzynarodowej do wypracowania i wdrożenia jakiejkolwiek realnej strategii zakończenia konfliktu syryjskiego. Jak się okazuje, przyniósł on nie tylko katastrofę humanitarną, ale również przyczynił się do wykreowania poważnej siły politycznej, otwarcie negującej porządek polityczny na Bliskim Wschodzie. Przyszłość tzw. Państwa Islamskiego jest trudna do przewidzenia. Po stronie swoich wrogów ma zarówno mocarstwa zachodnie, jak i państwa regionalne. Jednak twór ten nie zniknie z dnia na dzień. Rządzący nim dzihadyści pokazują, że dysponują odpowiednimi środkami, które są podstawą dla budowy konkretnej struktury politycznej. Działania skierowane przeciwko tzw. Państwu Islamskiemu, w postaci nalotów podejmowanych przez USA czy inne państwa zachodnie, nie doprowadzą do jego upadku. W takich okolicznościach potrzebna będzie typowa interwencja zbrojna. Otwarte pozostaje pytanie, kto miałby ją przeprowadzić i jakie przyniosłaby efekty dla całego Bliskiego Wschodu. 